\title{
EDITORIAL
}

Open Access

\section{Feeding the online: perspectives on food, nutrition and the online higher education}

\author{
F. Xavier Medina ${ }^{1 *}$, Ana Pinto de Moura², José Antonio Vázquez-Medina ${ }^{3}$, Jesús Frías ${ }^{4}$ and Alicia Aguilar ${ }^{1 *}$
}

\author{
* Correspondence: fxmedina@uoc. \\ edu; aaguilarmart@uoc.edu \\ ${ }^{1}$ Universitat Oberta de Catalunya, \\ Barcelona, Spain \\ Full list of author information is \\ available at the end of the article
}

\section{Introduction}

Food is a complex phenomenon encompassing issues as diverse as agriculture, biology, culture, health, environment, the emotions or the socio-economic field (de Garine, 1979; Douglas, 1979; López García, Mariano, \& Medina, 2016; Medina, Aguilar, \& Solé-Sedeño, 2014). In contemporary global context, the listed issues seem to be aligned, under an emerging food-and-health paradigm. Thus, within the shifts of the health discourses that have taken part in the building of what is called Food Modernity, nutritional narratives have reached new arenas of expression.

Food in society while primarily being a local focus, where communities or nations secured their own provision has become a global internationalise trade. The present food system has the potential to feed the whole of humanity and preventing hunger (D'Odorico, Carr, Laio, Ridolfi, \& Vandoni, 2014). However, society is identifying new challenges in terms of the healthiness and sustainability of the different diets (Dernini et al., 2017; Serra-Majem \& Medina, 2015) as whole food systems (the recently published and controversial article by Willett et al., 2019, should be a good example).On the other hand, the food field has developed and demands its own methodologies, increasingly seeking interdisciplinarity (de Garine, 2004; McClancy \& Macbeth, 2004). As Bosman and Eom (2019) points out in their article published in this collection, the benefit of exploring and designing around the theme of food science and technology exists in the transdisciplinary nature of food which covers the gamut of business viability and economic analysis, customer desirability and consumer behaviours, and technical feasibility and prototyping.

In this regard, both quantitative (especially in the case of nutrition, food science and biochemistry, but also some visions of sociology, eg. González Turmo \& Mataix, 2004; Mehta \& Allison, 2014) and, especially, qualitative approaches (from all those perspectives that correspond mainly to the social field, but not only, eg. Hubert, 2004; Medina, 2004) are actually demanding the light of a new and more specialized focus.

We have also to recognize that, in the last two and half decades, the Internet has taken over our lives. In this not-new-anymore environment, different aspects of our daily life have acquired an important presence in the virtual world: immediate communication, social networks, especially with the popularization of applications on mobile devices... But also different aspects of our daily life (from digital signatures to "going online" to the supermarket...). Within this context of internationalisation, food 
security, healthiness and sustainability, food has not been an exception and we can consider also that a new field has been opened.

Based on the need to tackle these interlinked topics, this special issue aims to raise awareness and help to adapt food related modules/courses to the new opportunities and educational challenges, with an emphasis on projects, case studies, innovative teaching methodologies in formal and lifelong learning training, and innovative experiences of the ICT curricular inclusion food related programmes.

\section{Food and the virtual: is the virtual world changing our food and/or food conceptions?}

The emergence of this field allows us to reformulate the idea of understanding food and/or nutrition in the present (virtual) world (Mariano, Medina, \& López García, 2017). Thus, according to Rousseau, new platforms such as blogs, webzines, Facebook, Instagram or Twitter have opened up as new spaces to talk about food. Virtual communities have flourished in a very short space of time through seemingly simple facts such as sharing recipes or stories beyond the traditional boundaries of place and profession (Rousseau, 2012: $\mathrm{x}$-xi).

New categories related to food, such as "Foodporn", "Gastrosphere", virtual "Foodies" or "Instafoodies", "Culinary bloggers", etc., emerge in a host of websites and social networks specializing in issues such as food aesthetics, wine and food tourism, reviews, recommendations and criticism of restaurants or products, production processes and food consumption, healthy diets and prescriptions, nutritional coaching, diet fades, environmental advise, provenance queries, social and political influence in foods or simply contacts and interpersonal and/or institutional influences (Aguilar et al., 2014; Mariano et al., 2017: 21-22).

The virtual world has transformed our conceptions of food, the way we access information, the way we buy food, and even our eating behaviours ... And, of course, it is also transforming the way we study food.

\section{On food and the online higher education: lights and shadows on interdisciplinarity, participation, skills and competencies}

Following this in a reflective fashion, we can observe a similar trend in the higher education teaching work. In the last two decades, and as Esteve points out, the European Higher Education Area has radically transformed university studies by placing the student at the centre of the educational process (Esteve, 2016). This new educational paradigm and its new implicit assessment of acquired skills forced teachers to rethink classical learning objectives (Correa \& de Pablos, 2009) and, in a framework like this, the potential that Information and Communication Technologies (ICT) have (Zayer, Beran, \& Alcaide-Pulido, 2017).

The way of observing teaching has changed, and has already overcome the old model of a passive presence without discussion (and without the possibility of reflection or dissension). As Aguilar and Medina (2017) points out, the virtual world, and specifically social networks can assist the training on different aspects of almost any specific topic. These tools allow the teaching and learning practitioner to overcome the limitations of the teaching classroom, increasing the interaction between students. Limitations that, 
otherwise, would not have reflected on a topic or they would have done it in a relatively precarious way within the strictly academic context.

On lights...

Higher education, and particularly postgraduate programmes in Food, Food Science, Nutrition and Health, take a multidisciplinary approach, combining subjects such as nutrition, food science, psychology and, more and more frequently, social and cultural perspectives. Following Bosman and Eom's (2019) review of literature in this collection, different research on food postgraduate virtual programmes showed important teaching-related benefits that have contributed in a significant way to the success of these programmes. In this regard, they show how authors like Cohen (2010) points out after his evaluation of a cross-disciplinary undergraduate course that integrates design and liberal arts intending to improve the sustainability of the school's food system, that the course was effective and helpful in learning about sustainability and urban systems through research, problem-solving, and communication. Barlett et al. (2008) conducted research in a multidisciplinary faculty professional development program that aimed to integrate sustainability and environmental issues related to food science and technology into the higher education curriculum. Data collected from ninety faculty participants showed an increased awareness of systems thinking, desire to change daily habits, motivation to get more involved in political action, and a value proposition for teaching living systems from a more holistic approach including the natural sciences, social sciences, and humanities.

On the other hand, Parr and Trexler (2011), who investigated student perceptions related to sustainable agriculture and food systems education, find a strong connection to experiential learning theory in that learning was enhanced when the knowledge was coconstructed by learning through both classroom theory and applied fieldwork. Regarding this same field (sustainable agriculture and food systems education), Galt, Clark, and Parr (2016) suggest that values can be used as a guiding learning element to promote participatory dialogue, increase awareness around personal thought and use of language, and facilitate agency and empowerment towards civic action. Galt et al. (2013) show also in their research how the students increased their learning through the inquiry process, and the reflective essays played an important role in reinforcing learning and allowing for instructors to understand the students' perceived learning.

\section{... And shadows}

But even if students can show a very high level of motivation and satisfaction with this courses and have the perception of having reached an effective learning outcome in knowledge, competences, attitudes and behaviours (Vaz-Fernandez \& Caeiro, 2019, in this collection), we find, on the other hand, the perception that there are still a number of challenges and problems that must be solved:

- it seem to be in this kind of programmes a gap existing between competencies and reality. In this regard, the students frequently face difficulties of connecting competencies to the real-world learning opportunities (Brundiers, Wiek, \& Redman, 2010);

- there are limited best practices and critical analysis related to curriculum design and teaching within these types of programs (Valley, Wittman, Jordan, Ahmed, \& Galt, 2018); 
- additional administrative support and long-term and institutional commitment (where efforts are provided beyond the classroom) is required to effectively design and implement courses that would involve more faculty and advance the college's mission (Barlett, 2011; Berger, Scott, Axe, \& Hawkins, 2013).

Finally, and regarding multidisciplinarity and/or interdisciplinarity, it should also be noted that some programmes, in order to achieve students' knowledge of certain subjects of the curricula of food sciences or health-related programmes, usually focus on scientific or experimental disciplines while ignoring the human/social aspect of the training (Aguilar, Medina, Pons, \& Saigí, 2013; De Garine, 2004; Owen et al., 2011). This fact is creating an important gap in skills on student achievement. As an example, the present understanding of sustainability and sustainable development goals requires an understanding of the economic, environmental and social aspects of food production. Not training the future professionals on the skills needed to understand social and humanities needs of communities, individuals will mean that we won't be equipped for the future global challenges of humanity (Assembly, G, 2015; Fien, 2002).

\section{Feeding the online: ICT, virtual networks and social and collaborative dimensions of learning}

The new conception (and the constant evolution) of virtual social networks affect our conception of the world, our capacity for observation and analysis, but also our abilities and expectations of learning. Tweeter (Chawinga, 2017), Instagram (Aguilar \& Medina, 2017) or blogging (Conde-Caballero, Castillo, Ballesteros-Yáñez, \& Mariano-Juárez, 2019, in the present Issue) are playing an increasingly important role as educational tools that allow the acquisition of skills in a more interactive way, especially in areas related to food and nutrition.

In this regard, a more holistic approach is considered in the European food studies programmes, where the central core of courses content considers food technology, consumer sciences, business and economics, food culture or nutrition and health studies (de Moura et al., 2010). This multidisciplinary approach is complemented with the Bologna Process for creating the European Higher Education Area, where specification of generic competencies that enable students to work in teams, to interact with other students and other subjects, to think critically is made within each programme (CRE, 2000).

On the other hand, advances in information and communications technologies (ICT) have exerted a tremendous impacts on the format and on the approach to teaching and learning. Most notably in terms of online education programmes (Hay, Peltier, \& Drago, 2004). These programmes provide the "modern" student a method of study that accommodates diversity, allowing to set individual learning objectives and course timeline (Azeiteiro, Bacelar-Nicolau, Caetano, \& Caeiro, 2015).

According to Carapeto and Barros (2019) in the current issue, nutrition education may be any set of learning experiences designed to facilitate the voluntary adoption of eating and other nutrition-related behaviours conductive to health and well-being. By extension, instead of only transmitting factual information on food, nutrition, health and food safety concepts and processes, higher education is to use experiential and interactive learning processes. With this learner centred approach the adoption of 
safety, healthy, and wellbeing food attitudes and behaviours will be encouraged. This transformative approach, along student personal and professional lives, has the potential of best supporting critical reflection (Shanley, Thompson, Leuchner, \& Zhao, 2004).

This fact is particularly relevant considering that the majority of online food programme students are, for the most part, working full-time and report job and employment goals as a reason for enrolling in online courses (de Moura et al., 2010; Medina, Càceres, \& Miró, 2018; Shanley et al., 2004). As pointed out also by Hansen (2008), the usefulness of online courses for developing skills leads to the application of class knowledge to the real world. At the end, each student in his/her daily life is a potential food consumer that has experienced food consumption decisions and/or a professional capable of influencing wide decisions in food production. They can support a critical reflection of what they learned, increasing their critical thinking capabilities, and, for example, reward more healthy and sustainable food products (Grunert, 2011).

Following social constructivism, that emphasizes the social dimension of individual's learning (Vygotsky, 1978), some researchers suggest that collaborative learning is crucial to enrich and increase online student learning experiences (Pallof \& Pratt, 2007; Vonderwell, 2003). Effective collaborative learning consists of students perceiving the importance of working actively with their peers in order to learn and act in ways which ameliorate the educational procedure and accentuates the value of cooperation. In online environment programmes, students comment on topics, criticise one others' comments, share materials and send their contributions, making their knowledge and professional skills achievement more explicit (De Moura \& Aires, 2018).

In addition, collaboration may regulate positive (e.g. engagement, excitement) and negative emotions (e.g. anger, frustration, confusion, boredom) from studying online, because interactions may help students to deal with interest and enthusiasm or stress and uncertainty (Berenson, Boyles, \& Weaver, 2008; O’Regan, 2003; Zembylas, 2008). Collaborative learning may be also achieved through the inclusion of support materials (teacher's slide presentations and original documents, video, audio, scientific papers, organisation framework papers, food regulations, and internet websites) and a number of activities, with an accompanying teacher support, such as asynchronous discussion forums, chat, blogs, surveys, glossaries, journals, wikis and quizzes, that appeals to a diversity of students with multiple learning styles (Aguilar et al., 2013).

\section{Conclusions}

The field related to food and nutrition, together with others such as health sciences in general, have been slow to develop effectively in relation to higher education online. However, its development, although late, has been effective and has not stopped advancing in recent years.

The different fields of action of the virtual world have become tools that, today, allow us to think about higher education on food in relation to areas that go far beyond the classroom. Regarding the food field, and following the different findings of the literature, we actually know that the higher education programmes on food, food sciences and nutrition provide greater involvement, interaction with peers, digital skills, management of social networks, as well as a greater perception of the applicability and usefulness of knowledge. 
However, despite the progress, there are still many problems and challenges to solve like gaps between competencies and reality; difficulties of connecting competencies to the real-world learning opportunities; a lack of administrative and/or institutional commitment, and even the lack of confidence of certain institutions and universities in the real possibilities of the online education, especially significant in those fields related to health sciences, of which food is one of its pillars.

As Carapeto and Barros (2019) points out in their article in this dossier, e-learning still remains a challenge for the food field, but also for all areas of knowledge. At the same time it breaks paradigms, it brings innovation and new perceptions in pedagogy, thus facilitating an alternative process of teaching and learning.

This fact seems to be evident for food, food sciences and nutrition higher education programmes. As food online courses and degree programmes are becoming available through most of universities and lifelong learning training modalities, there is a need for reliable information and data to support the legacy of these programmes: "Learning Anywhere Anytime for Anyone” (Blocher, De Montes, Willis, \& Tucker, 2002).

\section{Authors' contributions}

All authors read and approved the final manuscript

Funding

Not applicable.

Availability of data and materials

Not applicable.

Competing interests

The authors declare that they have no competing interests.

\section{Author details}

${ }^{1}$ Universitat Oberta de Catalunya, Barcelona, Spain. ${ }^{2}$ GreenUPorto/DCeT, Universidade Aberta, Porto, Portugal.

${ }^{3}$ Universidad Claustro de Sor Juana, Mexico City, Mexico. ${ }^{4}$ Technological University Dublin, Dublin, Ireland.

Published online: 06 November 2019

\section{References}

Aguilar, A., \& Medina, F. X. (2017). Alimentación, e-learning y redes sociales. Una experiencia de utilización docente de Instagram en relación con los mercados municipales y el consumo alimentario (food, e-learning and social networks. An experience of teaching use of Instagram in relation to municipal markets and food consumption). In L. Mariano, F. X. Medina, \& J. López García (Eds.), Comida y mundo virtual. Internet, redes sociales y representaciones visuales (food and virtual world. The internet, social networks and visual representations). Barcelona: Editorial UOC.

Aguilar, A., Medina, F. X., Pons, J. A., \& Saigí, F. (2013). Challenges and opportunities of 2.0 tools for the interdisciplinary study of nutrition: The case of the Mediterranean diet wiki. International Journal of Educational Technology in Higher Education, $10(1), 210-225$.

Aguilar, A., Solé-Sedeño, J. M., Mancebo-Moreno, G., Medina, F. X., Carreras-Collado, R., \& Saigí-Rubió, F. (2014). Use of mobile phones as a tool for weight loss: A systematic review. Journal of Telemedicine and Telecare, 20(6), 339-349.

Assembly, G (2015). Sustainable development goals. (SDGs), Transforming our world: the, 2030.

Azeiteiro, U. M., Bacelar-Nicolau, P., Caetano, F. J. P., \& Caeiro, S. (2015). Education for sustainable development through e-learning in higher education: Experiences from Portugal. Journal of Cleaner Production, 106(1), 308-319.

Barlett, P. F. (2011). Campus sustainable food projects: Critique and engagement. American Anthropologist, 113(1), $101-115$.

Barlett, P. F., Anderson, E., Boyer, J. C., Brunckhorst, D., Princen, T., \& Barlett, P. B. (2008). Reason and reenchantment in cultural change: Sustainability in higher education. Current Anthropology, 49(6), 1077-1098.

Berenson, R., Boyles, G., \& Weaver, A. (2008). Emotional intelligence as a predictor of success in online learning. The International Review of Research in Open and Distributed Learning, 9(2). https://doi.org/10.19173/irrodl.v9i2.385.

Berger, M., Scott, E., Axe, J., \& Hawkins, I. (2013). World challenge: Engaging sophomores in an intensive, interdisciplinary course. International Journal of Teaching and Learning in Higher Education, 25(3), 333-345.

Blocher, J. M., De Montes, L. S., Willis, E. M., \& Tucker, G. (2002). Online learning: Examining the successful student profile. Journal of Interactive Online Learning, 1(2), 1-12 http://www.ncolr.org/jiol/issues/PDF/1.2.2.pdf.

Bosman, L., \& Eom, S. (2019). Using scaffold innovation-thinking frameworks to integrate food science and technology into the transdisciplinary engineering design classroom. International Journal of Educational Technology in Higher Education (ETHE), 16(35) https://educationaltechnologyjournal.springeropen.com/articles/10.1186/s41239-019-0165-y.

Brundiers, K., Wiek, A., \& Redman, C. L. (2010). Real-world learning opportunities in sustainability: From classroom into the real world. International Journal of Sustainability in Higher Education, 11(4), 308-324. 
Carapeto, C., \& Barros, D. M. V. (2019). Nutrition and health as virtual class at Open University (Portugal): Pedagogical strategies for higher education. International Journal of Educational Technology in Higher Education (ETHE), 16(19) https:// educationaltechnologyjournal.springeropen.com/articles/10.1186/s41239-019-0151-4.

Chawinga, W. D. (2017). Taking social media to a university classroom: Teaching and learning using twitter and blogs. International Journal of Educational Technology in Higher Education (ETHE), 14(3) https://educationaltechnologyjournal. springeropen.com/track/pdf/10.1186/s41239-017-0041-6.

Cohen, N. (2010). Designing the sustainable foodshed: A cross-disciplinary undergraduate environmental studies course. Innovative Higher Education, 35(1), 51-60. https://doi.org/10.1007/s10755-009-9126-z.

Conde-Caballero, D., Castillo, C. A., Ballesteros-Yáñez, I., \& Mariano-Juárez, L. (2019). Blogging as a tool for the acquisition and dissemination of knowledge in health sciences: A preliminary evaluation. International Journal of Educational Technology in Higher Education (ETHE), 16(30) https://educationaltechnologyjournal.springeropen.com/articles/10.1 186/s41239-019-0161-2.

Correa, J. M., \& de Pablos, J. (2009). Nuevas tecnologías e innovación educativa. Revista de Psicodidáctica, 14(1), 133-145.

CRE (2000). The Bologna declaration on the European space for higher education: An explanation. The Confederation of EU Rectors' Conferences and the Association of European Universities (CRE) https://cplol.eu/images/Bologna_declaration_en.pdf.

De Garine, I. (1979). Culture et nutrition. Communications, 31, 70-92.

De Garine, I. (2004). Anthropology of food and Pluridisciplinarity. In J. McClancy, \& H. Macbeth (Eds.), Researching food habits. Methods and problems. Oxford: Berghahn.

De Moura, A. P., \& Aires, L. (2018). Food and sustainability: An emerging subject in sustainable environmental sciences education applying to the e-learning environment. In U. M. Azeiteiro, W. L. Filho, \& L. Aires (Eds.), Climate literacy and innovations in climate change education, (pp. 109-130). Cham: Springer.

de Moura, A. P., Cunha, L. M., Azeiteiro, U. M., Aires, L., Graça, P., \& Vaz de Almeida, M. D. (2010). Food consumer science postgraduate courses: Comparison of face-to-face versus online delivery systems. British Food Journal, 112(5), 544-556.

Dernini, S., Berry, E., Serra-Majem, L., La Vecchia, C., Capone, R., Medina, F. X., ... Trichopoulou, A. (2017). Med diet 4.0. The Mediterranean diet with four sustainable benefits. Public Health Nutrition, 20(7), 1322-1330.

D'Odorico, P., Carr, J. A., Laio, F., Ridolfi, L., \& Vandoni, S. (2014). Feeding humanity through global food trade. Earth's Future, 2(9), $458-469$.

Douglas, M. (1979). Les structures du culinaire. Communications, 31, 145-170.

Esteve, F. (2016). Bolonia y las TIC: De la docencia 1.0 al aprendizaje 2.0. La Cuestión Universitaria, 0(5), 58-67.

Fien, J. (2002). Advancing sustainability in higher education: Issues and opportunities for research. Higher Education Policy, 15(2), 143-152.

Galt, R. E., Clark, S. F., \& Parr, D. (2016). Engaging values in sustainable agriculture and food systems education: Toward an explicitly values-based pedagogical approach. Journal of Agriculture, Food Systems, and Community Development, 2(3), 43-54.

Galt, R. E., Parr, D., Kim, J. V. S., Beckett, J., Lickter, M., \& Ballard, H. (2013). Transformative food systems education in a land-grant college of agriculture: The importance of learner-centered inquiries. Agriculture and Human Values, 30(1), 129-142.

González Turmo, I., \& Mataix, J. (2004). Menthods for obtaining quantitative data on food habits in the first half of the twentieth century. In J. McClancy, \& H. Macbeth (Eds.), Researching food habits. Methods and problems, (pp. 161-168). Oxford: Berghahn.

Grunert, K. G. (2011). Sustainability in the food sector: A consumer behavior perspective. International Journal on Food System Dynamics, 2(3), 207-218.

Hansen, D. E. (2008). Knowledge transfer in online learning environments. Journal of Marketing Education, 30(2), 93-105.

Hay, A., Peltier, J., \& Drago, W. (2004). Reflective learning and on-line education: A comparison of traditional and on line MBA students. Strategic Change, 13(4), 169-182.

Hubert, A. (2004). Qualitative research in the anthropology of food. A comprehensive qualitative/quantitative approach. In J. McClancy, \& H. Macbeth (Eds.), Researching food habits. Methods and problems, (pp. 41-54). Oxford: Berghahn.

López García, J., Mariano, L., \& Medina, F. X. (2016). Usos y significados contemporáneos de la comida desde la antropología de la alimentación en América Latina y España (contemporary food uses and meanings from the anthropology of food in Latin-America and Spain). Revista de Dialectología y Tradiciones Populares (RDTP), 71(2), 327-370.

Mariano, L., Medina, F. X., \& López García, J. (2017). Introducción. Sobre alimentación y mundos virtuales (introduction. On food and virtual worlds). In L. Mariano, F. X. Medina, \& J. López García (Eds.), Comida y mundo virtual. Internet, redes sociales y representaciones visuales (food and virtual world. The internet, social networks and visual representations). Barcelona: Editorial UOC.

McClancy, J., \& Macbeth, H. (2004). Introduction: How to do anthropologies of food. In J. McClancy, \& H. Macbeth (Eds.), Researching food habits. Methods and problems, (pp. 1-14). Oxford: Berghahn.

Medina, F. X. (2004). 'Tell me what you eat and you will tell me who you are'. Methodological notes on the interaction between researcher and informants in the anthropology of food. In J. McClancy, \& H. Macbeth (Eds.), Researching food habits. Methods and problems, (pp. 55-62). Oxford: Berghahn.

Medina, F. X., Aguilar, A., \& Solé-Sedeño, J. M. (2014). Social and cultural aspects on obesity: Necessary reflections from public health. Nutrición clinica y Dietética hospitalaria, 34(1), 67-71.

Medina, F. X., Càceres, J., \& Miró, I. (2018). Projecte d'anàlisi d'impacte sobre el terreny d'un màster internacional sobre estudis alimentaris. El cas del Master's degree in food systems, society and international food governance (UOC). Revista del Congrés Internacional de Docència Universitària i Innovació (CIDUI), 4, 1-9 https://www.raco.cat/index.php/RevistaCIDUI/ article/view/349080/440250.

Mehta, T., \& Allison, D. B. (2014). From measurement to analysis reporting: Grand challenges in nutritional methodology. Frontiers in Nutrition, 1(6). https://doi.org/10.3389/fnut.2014.00006.

O'Regan, K. (2003). Emotion and e-learning. Journal of Asynchronous Learning Networks, 7(3), 78-92.

Pallof, R. M., \& Pratt, K. (2007). Building online learning communities: Effective strategies for the virtual classroom. San Francisco: Jossey-Bass.

Parr, D. M., \& Trexler, C. J. (2011). Students' experiential learning and use of student farms in sustainable agriculture education. Journal of Natural Resources \& Life Sciences Education, 40(1), 172-180.

Serra-Majem, L., \& Medina, F. X. (2015). The Mediterranean diet as an intangible and sustainable food culture. In V. R. Preedy, \& D. R. Watson (Eds.), The Mediterranean diet: An evidence-based approach, (pp. 37-46). Academic Press-Elsevier: London.

Shanley, E. L., Thompson, C. A., Leuchner, L. A., \& Zhao, Y. (2004). Distance education is as effective as traditional education when teaching food safety. Food Service Technology, 4(1), 1-8. 
Valley, W., Wittman, H., Jordan, N., Ahmed, S., \& Galt, R. (2018). An emerging signature pedagogy for sustainable food systems education. Renewable Agriculture and Food Systems, 33(5), 467-480. https://doi.org/10.1017/S1742170517000199.

Vaz-Fernandez, P., \& Caeiro, S. (2019). Students' perceptions of a food safety and quality e-learning course: A CASE study for a MSC in food consumption. International Journal of Educational Technology in Higher Education (ETHE), 16(37) https:// educationaltechnologyjournal.springeropen.com/articles/10.1186/s41239-019-0168-8.

Vonderwell, S. (2003). An examination of asynchronous communication experiences and perspectives of students in an online course: A case study. The Internet and Higher Education, 6(1), 77-90.

Vygotsky, L. S. (1978). In M. Cole, V. John-Steiner, S. Scribner, \& E. Souberman (Eds.), Mind in society: The development of higher psychological processes. Text edited by. Cambridge: Harvard University Press.

Willett, W., Rockström, J., Loken, B., Springmann, M., Lang, T., Vermeulen, S., ... Jonell, M. (2019). Food in the Anthropocene: The EAT-lancet commission on healthy diets from sustainable food systems. The Lancet, 393(10170), 447-492.

Zayer, L. T., Beran, S. N., \& Alcaide-Pulido, P. (2017). Exploring the challenges of social media use in higher education. In A. C. Scheinbaum (Ed.), The dark side of social media. Routledge. https://doi.org/10.4324/9781315167718.

\section{Publisher's Note}

Springer Nature remains neutral with regard to jurisdictional claims in published maps and institutional affiliations.

Submit your manuscript to a SpringerOpen ${ }^{\odot}$ journal and benefit from:

- Convenient online submission

- Rigorous peer review

- Open access: articles freely available online

- High visibility within the field

- Retaining the copyright to your article

Submit your next manuscript at $\boldsymbol{\nabla}$ springeropen.com 